\title{
CONSUMPTION OF MINAS FRESCAL CHEESE MAY BE A SOURCE OF HUMAN INFECTION BY Campylobacter jejuni
}

\author{
CONSUMO DE QUEIJO MINAS FRESCAL PODE SER UMA FONTE DE \\ INFECÇÃO HUMANA POR Campylobacter jejuni
}

\author{
Guilherme Paz MONTEIRO ${ }^{1 *}$; Roberta Torres de MELO ${ }^{1}$; Eliane Pereira MENDONÇA ${ }^{1}$; Priscila \\ Christen NALEVAIKO ${ }^{1}$; Mariela Moura CARREON ${ }^{1}$; Ana Beatriz Garcez BUIATTE ${ }^{1}$; Fernanda \\ Aparecida Longato SANTOS ${ }^{1}$; Carla Ribeiro PACHECO ${ }^{1}$; Yara Cristina de Paiva MAIA ${ }^{2}$; Daise \\ Aparecida ROSSI ${ }^{1}$ \\ 1. Laboratório de Biotecnologia Animal Aplicada, Universidade Federal de Uberlândia, Uberlândia, MG, Brasil; 2. Laboratório de \\ Nanobiotecnologia, Universidade Federal de Uberlândia, Uberlândia, MG, Brasil. *gui.paz@ hotmail.com
}

\begin{abstract}
Campylobacter spp. is an emerging pathogen that causes gastroenteritis in humans and the consumption of dairy food can characterize sources of infection. We aimed to verify the viability and a presence of transcripts associated with characteristics of virulence and adaptation of $C$. jejuni isolated from Minas Frescal cheeses, produced with contaminated milk and stored under refrigeration for up to ten days. The samples were analyzed for bioindicators, Campylobacter spp., $\mathrm{pH}$, acidity, moisture and sodium chloride. Campylobacter spp. recovered were evaluated for the production of transcripts of: ciaB, dnaJ, p19 and sodB. The results were correlated with the viability of $C$. jejuni and changes in their transcriptome. Storage at low temperatures reduced $C$. jejuni from the first to the fourth day. The variations in humidity, $\mathrm{pH}$ and acidity influenced the decreasing of $C$. jejuni. There was a reduction in transcripts' production of the four genes, more pronounced on the fourth day, indicating the inability of the microorganism to perform its metabolic activities, due to the conditions of injury. Despite the presence of mechanisms of virulence and adaptation, $C$. jejuni could not remain viable four days after production. However, consumption of fresh cheese contaminated with Campylobacter jejuni can be a source of infection when consumed up to four days after production.
\end{abstract}

KEYWORDS: Campylobacteriosis. Food safety. Gene transcription. Public health.

\section{INTRODUCTION}

Campylobacter spp. is currently the agent most involved in grastroenteritis cases in developed countries, with $C$. jejuni being the most prevalent specie (EFSA, 2017). It is also the microorganism most isolated from patients with food poisoning, exceeding about three to four times other enteric pathogens such as Salmonella spp. or Escherichia coli (WHO, 2012).

The clinical symptoms of Campylobacteriosis can range from mild to severe diarrhea, fever, vomiting and headaches and be the cause of other more serious complications such as GBS (Guillain-Barré Syndrome) (GOMES et al., 2018). While the poultry are incriminated as the main source of infection for humans, there is a high diversity of serotypes and genotypes when comparing isolates from humans and poultry, showing the existence of other sources of infection (FERNANDEZ; GARCÍA; VILLANUEVA, 2005).

The consumption of unpasteurized contaminated milk is also named as one of the major causes of acquisition of campylobacteriosis, as well as their derivatives. But little is discussed about the importance or danger of milk contamination and its derivatives after beneficiation and its consequences to human health.

It is believed that Campylobacter spp. can not survive to the manufacturing technology of matured cheeses added with lactic ferment. However, white and fresh cheeses, like Brazilian Minas Frescal cheese have high moisture content, and depending on the technology used, go through several processes of manipulation, with favorable conditions for contamination, survival and bacterial multiplication, including pathogenic species (CÂMARA et al., 2002) as Campylobacter jejuni. The recontamination of milk after pasteurization, or the refrigerated storage of cheeses near to raw or other unprotected foods can be possible opportunities of contamination by $C$. jejuni (LINHARES, 2012).

The Brazilian Minas Frescal cheese is a raw product with moisture content higher than $55 \%$ and usually without the addition of lactic ferment, conditions which can allow the survival of Campylobacter jejuni. The white cheeses in general, can be categorized as a high moisture cheeses (QUEIROZ et al., 2017), and have a pH around the 
neutrality, enabling the development of many microorganisms (SALOTTI et al., 2006).

This study aimed to verify in the Brazilian Minas cheese, manufactured with experimentally contaminated milk, with Campylobacter jejuni, the viability and the ability to produce virulence transcripts and stress response during refrigerated storage.

\section{MATERIAL AND METHODS}

The study was conducted at the Laboratory of Molecular Epidemiology at the Faculty of Veterinary Medicine of the Federal University of Uberlândia. For the experimental inoculation were used strains of C. jejuni NCTC 11351 (Microbiologics $($ ), and IAL 2383 from the Adolfo Lutz Institute - SP - Brazil. The IAL 2383 strain was isolated from clinical sample of a human patient during an outbreak, cataloged and already deposited on the IAL and characterized in previous studies (FONSECA et al., 2014).

Both strains were inoculated to achieve the concentration of $10^{5} \mathrm{CFU} . \mathrm{mL}^{-1}$ in pasteurized milk produced under federal inspection. The milk was previously analyzed and presented quality compatible with brazilian sanitary conditions contained in the Instruction $\mathrm{N}^{\circ} 62$ of December of 2011 (BRASIL, 2011).

\section{Cheese production}

For each strain were performed three productions, and a negative control. Each production of the test group consisted of $20 \mathrm{~L}$ of pasteurized milk inoculated with $10^{5} \mathrm{CFU} \cdot \mathrm{mL}^{-1}$ of C. jejuni, which resulted in three cheese units of approximately $0.5 \mathrm{~kg}$ each. The manufacturing conditions were described by Rossi (1997).
MONTEIRO, G. P. et al.

In the pre-heated milk at $40{ }^{\circ} \mathrm{C}$ was added in sequence: $1 \%$ of sodium chloride (Cisne $\left.{ }^{\circledR}\right)$ the inoculum of $C$. jejuni, $4,7 \mathrm{~mL}$ of lactic acid $85 \%$ (Flex ${ }^{\circledR}$ ), $10 \mathrm{~mL}$ of calcium chloride $50 \%$ (Labsynth (B) and $16 \mathrm{~mL}$ of liquid rennet to milk (Ha-La- Chr. Hansen $($ ). The negative control cheeses were produced under the same conditions, but using five liters of milk and without the inoculum.

After homogenization, the milk rested until coagulation (about 20 minutes) and the mass was cut into cubes of about $1 \mathrm{~cm}^{2}$. We proceeded to the point of mixture slowly, being the mass shaped without pressure, turning upside down the cheeses after 1 hour. After fabrication, the counting of Campylobacter spp. was performed in the whey produced by each cheese.

The cheeses were kept in a domestic refrigerator $\left(4-7^{\circ} \mathrm{C}\right)$ and analyzed after $1,4,7$ and 10 days of storage.

The total of cheeses produced in the test group was 18 (2 strains x 3 repetitions x 3 units of cheese). The control group made six cheeses (2 strains $\mathrm{x} 3$ repetitions $\mathrm{x} 1$ unit of cheese). The number of plots analyzed was 72 (18 cheeses x 4 periods) for the test group and 24 (4 cheeses $\times 6$ periods) for the control group.

It was determined the $\mathrm{pH}$, moisture content, sodium chloride and acidity (BRASIL, 2006) and have been counted Staphylococcus coagulasepositive, coliform group (SILVA et al., 2007) and Campylobacter spp. (ISO, 2006). The identification of $C$. jejuni strains was performed by a multiplex PCR (HARMON; RAMSOM; WESLEY, 1997).

The conduction of the study was in accordance with the fluxogram represented in Figure 1.

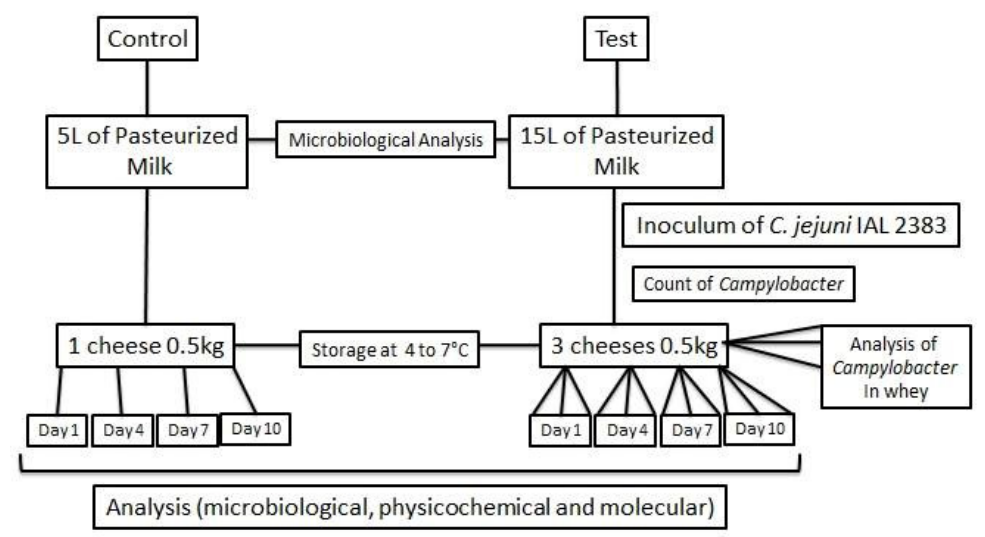

Figure 1. Demonstrative fluxogram of one of the repetitions for the strain C. jejuni IAL 2383.

The same procedure was performed to the strain, NCTC 11351. 


\section{Physicochemical analysis}

Before the fabrication of the cheeses, the milk was analyzed using commercial kits for the presence of phosphatase and peroxidase (LaborClin $\AA$ ) and residues of beta-lactam and tetracycline antibiotics (SNAP - Idexx Laboratories $\left.{ }^{\circledR}\right)$. Both performed as recommended by the manufacturers.

For the cheeses, the $\mathrm{pH}$ levels were determined with the aid of pHmeter (Tecnal and Tec-3MP model), previously calibrated with direct immersion of the potentiometer in the diluted sample in water. To determine the moisture was used the gravimetric method and the concentration of sodium chloride was obtained by titration with silver nitrate, both according to protocol described in Normative Instruction $\mathrm{N}^{\mathrm{o}} 68$ of the Ministry of Agriculture, Livestock and Supply (Ministério da Agricultura, Pecuária e Abastecimento) (BRASIL, 2006).

\section{Microbiological Analysis}

In milk was verified the presence of Campylobacter spp. in the $25 \mathrm{~mL}$ and quantified bioindicators, heterotrophic mesophilic bacteria, total coliforms and E. coli. For cheeses were measured: total coliforms, E. coli, Staphylococcus coagulase-positive and $C$. jejuni.

The heterotrophic mesophilic bacteria count was performed in the Plate Count Agar (PCA Standard agar for mesophilic bacteria) ( Difco $^{\mathrm{TM}}$ ) (MORTON, 2001); total coliforms and E. coli were quantified in Petrifilm (3M®). Staphylococcus coagulase-positive was determined in Baird Parker agar (Oxoid $\AA$ ) and suspected colonies was confirmed by tests of catalase, coagulase and DNase (LANCETTE; BENNETT, 2001).

The presence/absence of Campylobacter spp. in milk was performed according to the protocol described in ISO 10272-18 (ISO, 2006) with the pre-enrichment performed in Bolton broth (Oxoid®), followed by cultivation in plates of Campylobacter Blood-Free Selective Agar Base (mCCDA) (Oxoid $($ ), both added with their antibiotic supplements (Oxoid®) and incubated in microaerophilic atmosphere (5\% to $15 \%$ of oxygen and $10 \%$ of carbon dioxide) (Probac do Brasil®).

The enumeration of Campylobacter spp. in cheese was performed as recommended by ISO 10272-18 (ISO, 2006), under the same conditions used for milk, but without the pre-enrichment. Colonies were confirmed as the genus by the modified Gram stain (using carbol fuchsin replacing safranin) and catalase test.

\section{Identification of Campylobacter jejuni.}

The identification of $C$. jejuni strains was performed by multiplex PCR (HARMON; RAMSOM; WESLEY, 1997) DNA was extracted with the aid of commercially available kit (Wizard ${ }^{\circledR}$ Genomic DNA Purification Kit - Promega) following the protocol supplied by the manufacturer.

The preparation of PCR consisted of 20 picomoles of primer $\mathrm{C} 1$ and $\mathrm{C} 4,40$ picomoles of primers pg3 and pg50 (Table 1), $10 \mathrm{mM}$ of Tris$\mathrm{HCl}, \quad 50 \mathrm{mM}$ of $\mathrm{KCl}, 200 \mu \mathrm{M}$ of each deoxynucleotide triphosphates (DNTPs), $5.5 \mathrm{mM}$ of $\mathrm{MgCl}_{2}$ and $1,25 \mathrm{U}$ of Taq DNA polymerase and 20 ng of DNA (Invitrogen ${ }^{\circledR}$ ).

Table 1. Primers to $C$. jejuni e $C$. coli identifications

\begin{tabular}{|c|c|c|c|c|}
\hline Primers & Specie & Sequence $5{ }^{\prime} \rightarrow 3^{\prime}$ & $\begin{array}{l}\text { Molecular } \\
\text { Weight }\end{array}$ & Reference \\
\hline pg 3 & \multirow{2}{*}{$\begin{array}{l}\text { C. jejuni } \\
\text { and } \\
\text { C. coli }\end{array}$} & GAACTTGAACCGATTTG & \multirow[b]{2}{*}{$460 \mathrm{pb}$} & \multirow{2}{*}{$\begin{array}{l}\text { Harmon et al. } \\
\text { (1997) }\end{array}$} \\
\hline pg 50 & & ATGGGATTTCGTATTAAC & & \\
\hline $\begin{array}{l}\mathrm{C} 1 \\
\mathrm{C} 4\end{array}$ & C. jejuni & $\begin{array}{l}\text { CAAATAAAGTTAGAGGTAGAATGT } \\
\text { GGATAAGCACTAGCTAGCTGAT }\end{array}$ & $160 \mathrm{pb}$ & $\begin{array}{l}\text { Harmon et al. } \\
(1997)\end{array}$ \\
\hline
\end{tabular}

The amplification was according to the following steps: 1 initial denaturation cycle at $94{ }^{\circ} \mathrm{C}$ for 4 minutes; 25 cycles of: denaturation at $94{ }^{\circ} \mathrm{C}$ for 1 minute, annealing at $47{ }^{\circ} \mathrm{C}$ for 1 minute and extension at $72{ }^{\circ} \mathrm{C}$ for 1 minute, followed by a final extension cycle at $72{ }^{\circ} \mathrm{C}$ for 7 minutes (HARMON; RAMSOM; WESLEY, 1997).

The amplified products $(8 \mu \mathrm{L})$ were submitted to electrophoresis on agarose gel (1.5\% Afllymetrix $\left({ }^{\circledR}\right)$ in running buffer $0.5 \mathrm{x}$ TBE
(Invitrogen $\AA$ ) with the marker of $100 \mathrm{bp}$ (Invitrogen $\AA$ ) for 90 minutes at $100 \mathrm{~W}$ of potence, $80 \mathrm{~V}$ of voltage and electric current of $80 \mathrm{~A}$. The gels were stained with SYBR® Safe DNA gel stain solution (Invitrogen $®$ ) and visualized under UV light transilluminator (Loccus Biotecnologia).

\section{Production of Transcripts}

RNA extraction was performed according to Li et al. (2008) with modifications proposed by 
Melo (2012). The isolated from each sample, obtained by cultivation in four m-CCDA agar plates were transferred to microcentrifuge tubes containing $2 \mathrm{~mL}$ of $0.85 \% \mathrm{NaCl}$ solution (Synth®). The mixture was centrifuged at $12.000 \mathrm{~g}$ for ten minutes at $4{ }^{\circ} \mathrm{C}$. To the pellet obtained was added $1 \mathrm{~mL}$ of Trizol (Invitrogen $囚)$ and homogenized by vortexing (Phoenix $\left.{ }^{\circledR}\right)$. Then, $200 \mu \mathrm{L}$ of chloroform was added (Isofar $\AA$ ), and the procedure of homogenization was repeated by vortexing followed by centrifugation at $12.000 \mathrm{~g}$ for 15 minutes at $4{ }^{\circ} \mathrm{C}$.

The formed aqueous portion was transferred to a new microtube, which was added with $500 \mu \mathrm{L}$ of isopropanol (Sigma Aldrich®), again homogenized and centrifuged at $12,000 \mathrm{~g}$ for 10 minutes at $4{ }^{\circ} \mathrm{C}$. At the formed pellet was added 1 $\mathrm{mL}$ of ethanol $75 \%$ (Sigma-Aldrich®) and after homogenization and centrifugation at $7.500 \mathrm{~g}$ for 5 minutes at $4{ }^{\circ} \mathrm{C}$, the supernatant obtained was discarded. RNA pellets were dried at room temperature to be diluted in $20 \mu \mathrm{L}$ of DEPC water (Invitrogen $®)$. The quantification of RNA was performed in equipment Nanodrop spectrophotometer (Thermo Scientific®).

The reverse transcription polymerase chain reaction (RT-PCR) was used to evaluate the production of transcripts, as recommended by $\mathrm{Li}$ et al. (2008). The following steps was performed for each sample: $1 \mu \mathrm{g}$ of total RNA (200ng/uL), $10 \mathrm{U}$ of RNase inhibitor, $40 \mathrm{U}$ of MMLV-RT (Amersham Biosciences ()$, \quad 1 X$ of MMLV-RT buffer (Amersham Biosciences®), $200 \mu \mathrm{M}$ of $\mathrm{dNTP}$ (dGTP, dATP, dCTP and dTTP), 126 pmoles of hexamer oligonucleotides as random primers (Invitrogen $\AA$ ) and $20 \mu \mathrm{L}$ of DEPC water (Invitrogen $\AA$ ). The solution was placed in microfuge at $37{ }^{\circ} \mathrm{C}$ for one hour to obtain the cDNA.

Subsequently $3 \mu \mathrm{L}$ of cDNA was used for amplification reaction of $25 \mu \mathrm{L}$, composed of $0.625 \mathrm{U}$ of Taq DNA polymerase, $5 \mathrm{mM}$ of $\mathrm{MgCl}_{2}$, $200 \mathrm{mM}$ of dNTPs and 4 pmoles of each primer (Invitrogen $\AA$ ). The positive control, $C$. jejuni NCTC 11351 , and the negative control, consisting of sterile ultrapure water, were used in all amplification reactions.

The primers used to determine the gene transcription were: ciaB (invasion), dnaJ (thermotolerance), $p 19$ (iron transport during stress) and $\operatorname{sodB}$ (defense to oxidative stress), as shown in Table 2. C. jejuni strain NCTC 11351 show all these genes in its genome (BORGES, 2013; MELO et al., 2013).

Table 2. Primers used to verify the production of transcripts ciaB, dnaJ, p19 and sodB genes for C. jejuni.

\begin{tabular}{|c|c|c|c|}
\hline Genes & Sequence 5' 3' & Molecular weight (bp) & Reference \\
\hline$c i a B$ & $\begin{array}{l}\text { ATATTTGCTAGCAGCGAAGAG } \\
\text { GATGTCCCACTTGTAAAGGTG }\end{array}$ & 157 & Li et al. (2008) \\
\hline dnaJ & $\begin{array}{l}\text { AGTGTCGAGCTTAATATCCC } \\
\text { GGCGATGATCTTAACATACA }\end{array}$ & 117 & Li et al. (2008) \\
\hline p19 & GATGATGGTCCTCACTATGG & 206 & Birk et al. (2012) \\
\hline $\operatorname{sod} B$ & $\begin{array}{l}\text { CATTTTGGCGTGCCTGTGTA } \\
\text { TATCAAAACTTCAAATGGGG } \\
\text { TTTTCTAAAGATCCAAATTCT }\end{array}$ & 170 & Birk et al. (2012) \\
\hline
\end{tabular}

The amplification was performed in thermocycler, according to the following steps: 1 initial denaturation cycle at $94{ }^{\circ} \mathrm{C}$ for 3 minutes; 45 cycles of amplification in three stages: denaturation at $94{ }^{\circ} \mathrm{C}$ for 15 seconds, annealing at $51{ }^{\circ} \mathrm{C}$ for 20 seconds and extension at $72{ }^{\circ} \mathrm{C}$ for 20 seconds; completing with one more final cycle of extension at $72{ }^{\circ} \mathrm{C}$ for 3 minutes.

The separation of the amplified products was performed by electrophoresis on $1.5 \%$ agarose gel (Affymetrix®), using the TBE $0.5 \mathrm{X}$ buffer (Invitrogen $®)$ and as a molecular weight standard the 50bp marker (Invitrogen $®)$.

\section{Evaluation of the results}

The results were analyzed using the Minitab program. The test $t$ paired and unpaired was used to verify differences between the means of physicochemical analysis and the Pearson test to correlate microbiological and physicochemical results with the survival of Campylobacter jejuni in cheese. The association between the strain and the ability to produce transcripts was evaluated by chisquare test. $\left(\chi^{2}\right)$.

\section{RESULTS AND DISCUSSION}

After experimental inoculation, the mean count of both strains of Campylobacter jejuni in milk was $3.0 \times 10^{5}$ CFU.mL ${ }^{-1}$, with no significant 
difference between the counts in the different fabrications ( $>$ 0.05). The inoculated microorganisms were detected in the whey obtained from the fabrication of cheese, with counts ranging from $10^{3}$ CFU. $\mathrm{mL}^{-1}$ to $10^{4} \mathrm{CFU} \cdot \mathrm{mL}^{-1}$, demonstrating that the microorganism remained viable during processing.

The presence of $C$. jejuni in the whey shows that if the cheese is produced with contaminated milk, this can become a source of contamination of the facilities and other derivatives, depending on the fluxogram of production and distribution of dairy manufacturing sites.

The detection of Campylobacter spp. in cheese samples was possible only in day 1 and day 4 after the production, in both were performed analyzes to verify presence/absence and the counts for all tested strains, we found a total of $36 / 72$ $(50.0 \%)$ of positive samples. Silva et al. (2007) found values above $80 \%$ in 18 Brazilian Minas cheese produced with raw milk.

In counting, it was observed that in all plates with growth, the colonies had the confluent form, with film-look, making it impossible to determine the exact count. Therefore, the quantification was done based only on calculation of the inverse of the highest dilution plates used in the presence of Campylobacter spp. For example, if Campylobacter was detected until the third dilution of the sample, the result is given by multiplying by the inverse of the dilution, in this case $10^{3}$ CFU.mL ${ }^{-}$ ${ }^{1}$, if detected until the fourth dilution the result is $10^{4}$ CFU.mL $L^{-1}$ and so on.

Table 3. Campylobacter jejuni $\left(\mathrm{CFU} . \mathrm{g}^{-1}\right)$ recovered from Minas Frescal cheese fabricated with experimentally contaminated milk after storage at $4{ }^{\circ} \mathrm{C}$ for 10 days.

\begin{tabular}{lllllll}
\hline \multicolumn{7}{l}{ Inoculated strain of $\boldsymbol{C}$. jejuni $^{\mathbf{1}}$} \\
\hline Fabrication & $\mathbf{1}$ & \multicolumn{3}{l}{} & $\mathbf{2}$ & \\
\hline Storage (Days) & NCTC & IAL & NCTC 11351 IAL & NCTC 11351 IAL \\
& $\mathbf{1 1 3 5 1}$ & $\mathbf{2 3 8 3}$ & & $\mathbf{2 3 8 3}$ & & $\mathbf{2 3 8 3}$ \\
\hline $\mathbf{1}$ & $10^{5}$ & $10^{5}$ & $10^{5}$ & $10^{5}$ & $10^{5}$ & $10^{5}$ \\
$\mathbf{4}$ & $10^{3}$ & $10^{3}$ & $10^{2}$ & $10^{3}$ & $10^{2}$ & $10^{3}$ \\
$\mathbf{7}$ & $<10^{1 *}$ & $<10^{1 *}$ & $<10^{1 *}$ & $<10^{1 *}$ & $<10^{1 *}$ & $<10^{1 *}$ \\
$\mathbf{1 0}$ & $<10^{1 *}$ & $<10^{1 *}$ & $<10^{1 *}$ & $<10^{1 *}$ & $<10^{1 *}$ & $<10^{1 *}$ \\
\hline
\end{tabular}

${ }^{1} 10^{5}$ CFU.mL ${ }^{-1}$ of $C$. jejuni NCTC 11351 and IAL 2383 in the milk. Mean of three samples in duplicate.

* Test detection limit.

There was a significant decrease $(\mathrm{p}<0.001)$ in the number of $C$. jejuni during the refrigerated storage period in brazilian Minas Frescal cheeses, from the first to the fourth day. The counts in the samples inoculated with $C$. jejuni NCTC 11351 presented a mean reduction of three log cycles $\left(10^{5}\right.$ to $\left.10^{2} \mathrm{CFU} \cdot \mathrm{g}^{-1}\right)$ and the IAL 2383 strain presented reduction of two log cycles $\left(10^{5}\right.$ to $\left.10^{3} \mathrm{CFU} \cdot \mathrm{g}^{-1}\right)$, making it not culturable in seventh and tenth days (Table 3). Some hypotheses are possible to explain the reduction: 1) the microorganism may have assumed the viable non culturable form (VNC), which is typical of the agent under stress conditions, such as low temperatures (HUMPHREY; O'BRIEN; MADSEN, 2007), aerobic conditions, acid stress, starvation (GÖLZ et al., 2018); 2) difficulties to support the storage conditions; or, 3) the microorganism was below the detection limit of the analysis technique.

On the fourth day of storage was observed changes in the morphology of Campylobacter spp., with some cells with coccoid form, suggesting that the most probable hypothesis is that the microorganism assumed the VNC form. According
Debruyne et al. (2008), this form is obtained in cultures with more than three days, or when they are under stress situations, in which the cells of Campylobacter spp. assume spherical or ovoid shapes with loss of its ability to multiply in culture media, which makes it difficult to cultivate it in the laboratory, but this is a survival strategy of this agent, which remains infectious. Campylobacter spp. in VNC state are able to initiate biofilm formation, and are still infective (GÖLZ et al., 218). The microorganism was not recovered from the cheese in the later days.

Considering the low infective dose of Campylobacter spp., around 500 cells (CHAISOWWONG et al., 2012), and the general preference of population for the consumption of more fresh products, it can be inferred that, by the fourth day after production, the consumption of contaminated cheeses can offer a threat of infection to consumer. If $C$. jejuni has degenerated to the form of VNC cells, this risk may be extended.

The counts of bioindicators in cheese have had acceptable range allowed by the legislation and there was no correlation between its results and the 
viability of $C$. jejuni. Already the levels of moisture content, $\mathrm{pH}$ and acidity were correlated with the survival of strains $(\mathrm{p}<0.05)$. Thus, both the decreased of moisture and $\mathrm{pH}$ and the increasing of the acidity in the cheeses were correlated with the decreased of $C$. jejuni's viability.
The verification of the transcripts' production was possible only in the samples which the viable cells were recovered. The Table 4 divides the strains isolated from the cheeses in each one of the repetitions and storage periods, which were analyzed for the transcripts' production.

Table 4. Strains* recovered from the samples of Minas Frescal cheese experimentally contaminated.

\begin{tabular}{lllll}
\hline Repetition & Cheese & Day 1 & Day 4 & Total \\
\hline & 1 & A, B & A, B & 4 \\
1 & 2 & A, B & B & 3 \\
& 3 & A, B & A, B & 4 \\
\hline \multirow{2}{*}{2} & 1 & A, B & B & 3 \\
& 2 & B & B & 2 \\
\hline & 3 & A & - & 1 \\
\hline Total & 1 & A, B & B & 3 \\
& 2 & B & - & 1 \\
\hline
\end{tabular}

*A (strain NCTC); B (strain IAL).

In total were evaluated 23 samples that presented viable cells to transcripts production, being nine coming from the strain NCTC 11351 (seven retrieved from day one and two from day 4) and 14 strains of IAL 2383 (eight from day 1 and six from day 4).
The difference in the number of recovered samples shows that the NCTC strain demonstrated higher injury than IAL strain, but the difference was not significant $(\mathrm{P}>0.05)$.

The production of transcripts was evident on day 1 compared to day 4 for all the studied genes (Table 5).

Table 5. Transcription profile for $c i a B$, dnaJ, p19 and sodB genes by Campylobacter jejuni NCTC 11351 and IAL 2383, recovered from Minas Frescal cheese after refrigerated storage.

\begin{tabular}{llllll}
\multirow{2}{*}{ Genes } & NCTC 11351 & \multicolumn{5}{c}{ IAL 2383 } & Total \\
\cline { 2 - 5 } & Day 1 & Day 4 & Day 1 & Day 4 & $+/ \mathrm{N}(\%)$ \\
\cline { 2 - 5 } & $+/ \mathrm{n}(\%)$ & $+/ \mathrm{n}(\%)$ & $+/ \mathrm{n}(\%)$ & $+/ \mathrm{n}(\%)$ & $16 / 23(69.6)$ \\
ciaB & $4 / 7(57.1)$ & $1 / 2(50.0)$ & $8 / 8(100)$ & $3 / 6(50.0)$ & $19 / 23(82.6)$ \\
$\boldsymbol{d n a J}$ & $6 / 7(85.7)$ & $1 / 2(50.0)$ & $8 / 8(100)$ & $4 / 6(66.7)$ & $3 / 23(13.4)$ \\
sodB & $1 / 7(14.3)$ & $0 / 2(0)$ & $2 / 8(25.5)$ & $0 / 6(0)$ & $4 / 23(17.4)$ \\
\hline
\end{tabular}

$+/ \mathrm{n}$ : number of isolates capable of producing transcripts/total number of isolates recovered at each storage period. $+/ \mathrm{N}$ : total number of transcripts of each gene/total number of analyzed samples. (\%): percentage found in the total.

The NCTC and IAL strains even in stressful conditions transcribed characteristics of virulence, which can mean a risk to the consumer. Although, both possess the genes of cold adaptation ( $\operatorname{sodB}$ and p19), most of the recovered isolates produced no transcripts for these genes, which may have contributed to the loss of viability after the fourth day.

The $c i a B$ gene encodes a protein involved in cell invasion and survival (GOMES et al., 2018) and is considered as a reference in the study of pathogenicity of Campylobacter spp. (ZHENG et al.,2006; RAEISI et al., 2017). Percentually, IAL strain showed higher transcripts production capacity for this gene than the NCTC strain on day 1, reinforcing its greatest potential to cause disease, even in adverse conditions. The production of transcripts for this gene can interfere in the ability of C. jejuni to cause the disease or in its severity (ZIPRIN et al., 2001).

The highest percentage of transcripts for $c i a B$ of the IAL 2383 strain may be related to the 
intrinsic characteristics of the strain, since it was isolated from an outbreak in humans. A study by Fonseca et al. (2014) with the IAL 2383 strain showed that due to the virulence potential, it may be used as a useful model for studies related to pathogenicity.

The dnaJ gene is associated with thermotolerance and stress response (MELO et al., 2017), and presents relevant when it comes to variations in temperature (STINTZI; WHITWORTH, 2003). The transcription pattern for this gene was numerically similar to that found for $c i a B$ in both strains. The reduction of percentage in the numbers of $d n a J$ gene transcripts for day one to day four may be related to suppression of expression of this characteristic, detected when $C$. jejuni is subjected to cold stress shock (LITWIN; CALDERWOOK, 1993).

The $p 19$ gene encodes a periplasmic iron-dependent protein whose function is to transport iron, which is a component having low bioavailability into the mammalian host relative to the external environment (BIRK et al., 2012). The reduced ability to produce transcripts for p19 (3/23), which was observed only on the first day, may be related to low iron levels in milk and cheese (ANGELIS; CTENAS, 1993).

The $\operatorname{sod} B$ gene participates in the oxidative stress response (TORRES et al., 2017; GOMES et al, 2018) metabolizing toxic forms of oxygen, hydrogen peroxide and free radicals (PURDY et al., 1999). The transcription behavior for this gene was similar to that observed for the $p 19$ gene, being observed only at day one. The possible link between these two genes has been observed in another study (MOURA, 2013).

The variation in the production of transcripts by $C$. jejuni strains indicate that this species is able to modulate their transcriptome according to changes in environmental conditions, which can influence the potential of the pathogenic strains (MELO et al., 2013).

It is important to monitor the presence of Campylobacter spp. in cheeses of high moisture content and care to prevent contamination of already pasteurized milk used in manufacturing. Domestically, during handling and refrigerated storage, it should avoid behaviors that can promote cross-contamination, as there is a possibility of $C$. jejuni remain viable in this variety of cheese.

\section{CONCLUSION}

The conditions of processing and storage of Minas Frescal cheese reduce the viability and the ability to produce virulence transcripts by Campylobacter jejuni, but is unable to ensure its safety in case of the bacteria is present in the milk used for the manufacture or subsequently contaminate the cheese. Thus, the consumption of contaminated Minas Frescal cheese can be a source of infection for humans.

\section{ACKNOWLEDGEMENTS}

To FAPEMIG for financial support in the implementation of the study.

RESUMO: Campylobacter spp. é um patógeno emergente que causa gastroenterite em seres humanos e o consumo de produtos lácteos pode caracterizar fontes de infecção. O objetivo deste estudo foi verificar a viabilidade e a presença de transcritos associadas a características de virulência e adaptação de $C$. jejuni isoladas de queijos frescos, produzidos com leite contaminado e mantidos refrigeradas por dez dias. Foram analisados bioindicadores, Campylobacter spp., $\mathrm{pH}$, acidez, umidade e cloreto de sódio. Campylobacter spp. recuperados foram avaliados quanto à produção dos transcritos: ciaB, dnaJ, p19 e sodB. Os resultados foram correlacionados com a viabilidade de $C$. jejuni e alterações no transcriptoma. $\mathrm{O}$ armazenamento em baixas temperaturas reduziu $C$. jejuni do primeiro ao quarto dia. As variações na umidade, $\mathrm{pH}$ e acidez influenciaram a queda de $C$. jejuni. Houve uma redução na produção de transcritos dos quatro genes, mais pronunciada no quarto dia, indicando a incapacidade do micro-organismo em realizar suas atividades metabólicas, devido às condições de injúria. Apesar da presença de mecanismos de virulência e adaptação, $C$. jejuni não permaneceu viável quatro dias após a produção. Porém, o consumo de queijo fresco contaminado com Campylobacter jejuni pode ser uma fonte de infecção quando consumido até quatro dias após a produção.

PALAVRAS-CHAVE: Campilobacteriose. Segurança alimentar. Transcrição gênica. Saúde pública. 


\section{REFERENCES}

ANGELIS, R. C. D.; CTENAS, M. L. Biodisponibilidade de ferro na alimentação infantil. Nestlé, Temas de Pediatria, v. 52, p. 33, 1993.

BRASIL. Instrução Normativa no 68, de 12 de dezembro de 2006. Oficializa os Métodos Analíticos Oficiais Físico-Químicos, para Controle de Leite e Produtos Lácteos. Brasília, DF: Ministério da Agriultura, Pecuária e Abastecimento, 2006.

BRASIL. Instrução Normativa ${ }^{\circ}$ 62, de 29 de dezembro de 2011. Aprova o Regulamento Técnico de Produção, Identidade e Qualidade do Leite tipo A, o Regulamento Técnico de Identidade e Qualidade de Leite Cru Refrigerado, o Regulamento Técnico de Identidade e Qualidade de Leite Pasteurizado e o Regulamento Técnico da Coleta de Leite Cru Refrigerado e seu Transporte a Granel Brasília, DF: Ministério da Agricultura, Pecuária e Abastecimento, 2011.

BIRK, T.; WIK, M. T.; LAMETSCH, R.; KNOCHEL, S. Acid stress response and protein induction in Campylobacter jejuni isolates with different acid tolerance. BioMed Central Microbiology, v. 12, 174, p. 1-13, 2012. https://doi.org/10.1186/1471-2180-12-174

BORGES, L. W. Transcritos de virulencia por Campylobacter jejuni isoladas de carcaças de frango de corte. 2013. Monografia (Faculdade de Medicina Veterinária) - Curso de Medicina Veterinária, Universidade Federal de Uberlândia, Uberlândia, 2013.

CÂMARA, S. A. V.; AMARAL, G. B.; MULLER, M. T.; SILVEIRA, K. C. S.; ALMEIDA, T. N.; MEDEIRO, C. F. Avaliação microbiológica de queijo minas frescal artesanal, comercializados no mercado municipal de Campo Grande, Mato Grosso do Sul. Revista Higiene Alimentar, v. 16, p. 32-36, 2002.

CHAISOWWONG, W.; KUSUMOTO, A.; HASHIMOTO, M.; HARADA, T.; MAKLON, K.; KAWAMOTO, K. Physiological Characterization of Campylobacter jejuni under Cold Stresses Conditions: Its Potential for Public Threat. Journal of Veterinary Medical Science, v. 74, p. 43-50, 2012. https://doi.org/10.1292/jvms.110305

DEBRUYNE, L.; GEVERS, D.; VANDAMME, P. Taxonomy of the family Campylobacteraceae. In: NACHAMKIN, I.; SZYMANSKI, C. M.; BLASER, M. J. (Ed.). Campylobacter. Washington: American Society for Microbiology, 2008, p. 3-26.

EFSA (European Food Safety Authority). 2017. The European Union Summary Report on Trends and Sources of Zoonoses, Zoonotic Agents and Food-borne Outbreaks in 2016. EFSA Journal, European Food Safety Authority, 2017;15(12):5077, 228 p. https://doi.org/10.2903/j.efsa.2017.5077

FERNANDEZ, H.; GARCÍA, A.; VILLANUEVA, M. P. Serotipos de Campylobacter jejuni ssp. jejuni aislado de ave para consumo humano y en muestras de heces de niños com diarrea. Archivos de Medicina Veterinaria, v. 37, p. 79-81, 2005. https://doi.org/10.4067/S0301-732X2005000100013

FONSECA, B. B.; ROSSI, D. A.; MAIA, C. A.; NALEVAIKO, P. C.; MELO, R. T.; CUCCATO, L. P.; BELETTI, M. E. Characterization of the virulence, growth temperature and antibiotic resistance of the Campylobacter jejuni IAL 2383 strain isolated from humans. Brazilian Journal of Microbiology, v. 45, p. 271-274, 2014. https://doi.org/10.1590/S1517-83822014000100039

GÖLZ, G.; KITTLER, S.;VMALAKAUSKAS, M.; ALTER, T. Survival of Campylobacter in the Food Chain and the Environment. Current Clinical Microbiology Reports, v. 5, n. 2, p. 126 - 134, 2018.

https://doi.org/10.1007/s40588-018-0092-z 
GOMES, C. N.; PASSAGLIA, J.; VILELA, F. P.; SILVA, F. M. H. S. P. da.; DUQUE, S. S.; FALCÃO, J. P. High survival rates of Campylobacter coli under different stress conditions suggest that more rigorous food control measures might be needed in Brazil. Food Microbiology, v. 73, p.327-333, 2018. https://doi.org/10.1016/j.fm.2018.02.014

HARMON, K. M.; RAMSOM, G. M.; WESLEY, I. V. Differentiation of Campylobacter jejuni and Campylobacter coli by polymerase chain reaction. Molecular and Cellular Probes, v. 11, p. 195-200, 1997. https://doi.org/10.1006/mcpr.1997.0104

HUMPHREY, T.; O'BRIEN, S.; MADSEN, M. Campylobacter as zoonotic pathogens: a food production perspective. International Journal of Food Microbiology, v. 117, p. 237-257, 2007.

https://doi.org/10.1016/j.ijfoodmicro.2007.01.006

ISO - International Standards Organization. ISO 10272-1. 2006. Microbiology of food and animal feeding stuffs - Horizontal method for detection and enumeration of Campylobacter spp. - Part 1: detection method. ISO 10272-1:2006.

LANCETTE G. A.; BENNETT R.W. Staphylococcus aureus and staphylococcal enterotoxins. In: DOWNES, F.P.; ITO, K. (Ed.), Compendium of Methods for the Microbiological Examination of Foods, Washington: American Public Health Association, 2001. p. 387-403. https://doi.org/10.2105/9780875531755ch39

LI, Y.P.; INGMER, H.; MADSEN, M.; BANG, D.D. Cytokine responses in primary chicken embryo intestinal cells infected with Campylobacter jejuni strains of human and chicken origin and the expression of bacterial virulence-associated genes. BMC Microbiology, v. 8, p. 107, 2008. https://doi.org/10.1186/1471-2180-8-107

LINHARES, I. W.. Avaliação das condições higiênico-sanitárias no preparo de fórmulas infantis em lactário hospitalar. 2012. Dissertação (Mestrado em Farmácia) - Curso de pós-graduação em Farmácia, Universidade Federal de Minas Gerais, Belo Horizonte. 2012.

LITWIN, C. M.; CALDERWOOK, S. B. Role of iron in regulation of virulence genes. Clinical Microbiology Reviews, v. 6, p. 137-149, 1993. https://doi.org/10.1128/CMR.6.2.137-149.1993

MELO, R. T. Fatores de patogenicidade e potencial risco à saúde em Campylobacter spp. isolados de carcaças de frangos. 2012. Dissertação (Mestrado em Ciências Veterinárias) - Curso de pós graduação em Ciências Veterinárias, Universidade Federal de Uberlândia, Uberlândia, 2012.

MELO, R.T.; NALEVAIKO, P.C.; MENDONÇA, E.P.; BORGES, L.W.; FONSECA, B.B.; BELETI, M.E.; ROSSI, D.A. Campylobacter jejuni strains isolated from chicken meat harbor several virulence factors and represent a potential risk to humans. Food Control, v. 33, p. 227-23, 2013.

https://doi.org/10.1016/j.foodcont.2013.02.032

MELO, R. T.; MENDONÇA, E. P. ; MONTEIRO, G. P. ; SIQUEIRA, M. C. ; PEREIRA, C. B. ; PERES, P. A. B. M. ; FERNANDEZ, H. ; ROSSI, D. A. . Intrinsic and extrinsic aspects on Campylobacter jejuni biofilms. Frontiers in Microbiology, v. 8, p. 1-15, 2017. https://doi.org/10.3389/fmicb.2017.01332

MORTON, R. D. A. Aerobic plate count. In: DOWNES, F.P.; ITO, K. (Ed.), Compendium of Methods for the Microbiological Examination of Foods, Washington: American Public Health Association, 2001. p. 63-67. https://doi.org/10.2105/9780875531755ch07

MOURA, M. S. Influência de crioprotetores e pré-adaptação na viabilidade e produção de transcritos por cepas de Campylobacter jejuni mantidas a -20 ${ }^{\circ} \mathrm{C}$. 2013. Dissertação (Mestrado em Ciências Veterinárias) Curso de pós graduação em Ciências Veterinárias, Universidade Federal de Uberlândia, Uberlândia, 2013. 
PURDY, D.; CAWTHRAW, S.; DICKINSON, J. H.; NEWELL, D. G.; PARK, S. F. Generation of a superoxide dismutase (SOD)-deficient mutant of Campylobacter coli: evidence for the significance of SOD in Campylobacter survival and colonization. Applied and Environmental Microbiology, v. 65, p. 2540-2546, 1999. https://doi.org/10.1128/AEM.65.6.2540-2546.1999

QUEIROZ, M. M.; ROSSI, B. F.; CASTILHO, I. G.; RALL, V. L. M. Hygienic-sanitary quality of Minas fresh cheese sold in the city of Botucatu, São Paulo. Arquivo do Instituto Biológico, v.84, p. 1-6, 2017. https://doi.org/10.1590/1808-1657000292016

RAEISI, M.; KHOSHBAKHT, R.; GHAEMI, E. A.; BAYANI, M.; HASHEMI, M.; SEYEDGHASEMI, N. S.; SHIRZAD-ASKI, H. Antimicrobial Resistance and Virulence-Associated Genes of Campylobacter spp. Isolated from Raw Milk, Fish, Poultry, and Red Meat. Microbial Drug Resistance, v. 23, n. 7, p.925-933, 2017. https://doi.org/10.1089/mdr.2016.0183

ROSSI, D. A. Utilização do Coalho Bovino e Coagulantes Microbiano e Genético na Elaboração do Queijo Minas Frescal. 1997. Dissertação (Mestrado em Ciências dos Alimentos) - Curso de Pós-Graduação em Ciências dos Alimentos, Universidade Federal de Lavras, Lavras, 1997.

SALOTTI, B. M.; CARVALHO, A. C. F. B.; AMARAL, L. A.; VIDAL-MARTINS, A. M. C.; CORTEZ, A. L. Qualidade Microbiológica do Queijo Minas Frescal Comercializado no Município de Jaboticabal, SP, Brasil. Arquivo do Instituto Biológico, v. 73, p. 171-175, 2006.

SILVA, N. da.; JUNQUEIRA, V. C. A.; SILVEIRA, N. F. de A.; TANIWAKI, M. H.; SANTOS, R. F. S. dos; GOMES, R. A. R.; OKAZAKI, M. M. Manual de métodos de análise microbiológica de alimentos. 3. ed. São Paulo: Varella. 2007. 552 p.

STINTZI, A.; WHITWORTH, L. Investigation of the Campylobacter jejuni Cold-Shock Response by Global Transcript. Genome Letters, v. 2, p. 18-27, 2003.

WHO (World Health Organization). 2012. The global view of campylobacteriosis. Utrecht, Netherlands, 9-11.

ZIPRIN, R.L.; YOUNG, C.R.; BYRD, J.A.; STANKER, L.H.; HUME, M.E.; GRAY, S.A.; KIM, B.J.; KONKEL, M.E. Role of Campylobacter jejuni potential virulence genes in cecal colonization. Avian Diseases, v. 45, p. 549-557, 2001. https://doi.org/10.2307/1592894

ZHENG, J.; MENG, J.H.; ZHAO, S.H.; SINGH, R.; SONG, W.X. Adherence to and invasion of human intestinal epithelial cells by Campylobacter jejuni and Campylobacter coli isolates from retail meat products. Journal of Food Protection, v. 69, p. 768-774, 2006. https://doi.org/10.4315/0362-028X-69.4.768 